Indonesian Journal of Theology 7/1 (July 2019): 25-45

\title{
KETERKAITAN PENDIDIKAN KRISTIANI DI SEKOLAH DAN GEREJA
}

\author{
Justitia Vox Dei Hattu
}

\begin{abstract}
This article aims to map the polarization in Indonesia between Christian Education (or: Christian Religious Education) as it takes place within the domains of church and of school. Within the ecclesial arena, Christian education (Pendidikan Kristiani/PK) is often associated with the activity of teaching children. On the other hand, within the setting of a school, PK is often associated with a course of study assigned to students — one that mostly emphasizes the filling of cognitive gaps for the students yet (intentionally) ignores the affective and psychomotor domain that is integral for instruction. By examining this polarization, I argue that the polarizing divide between PK as implemented in a school and PK as implemented in the church can be overcome by virtue of the fact that both school and church are learning spaces for PK. This article is divided into three parts. The first will demonstrate certain misunderstandings about PK in the context of school and of church that lead to polarization. The second part shows how PK is presently practiced in the context of Indonesia's churches and schools. Based on descriptions in this second part, the final section will offer a number of basic principles, in an effort to bridge the gap between PK as it takes place in school and in church.
\end{abstract}

Keywords: Christian education, school, church, polarization.

\begin{abstract}
Abstrak
Tulisan ini bertujuan untuk memetakan polarisasi yang terjadi pada Pendidikan Kristiani (atau: Pendidikan Agama Kristen) ${ }^{1}$ dalam ranah
\end{abstract}

\footnotetext{
1 Kadarmanto Hardjowasito dalam Kata Pengantarnya di buku Memperlengkapi Bagi Pelayanan dan Pertumbuhan: Kumpulan Karangan Pendidikan Kristiani dalam Rangka Penghormatan kepada Pdt. Prof. Dr. Robert R. Boehlke, menjelaskan bahwa, "Dalam perkembangannya nama itu (dhi. PAK) mengalami distorsi makna, yaitu ketika PAK dipahami oleh publik sebagai pelajaran agama di sekolah-sekolah dan perguruan tinggi. Sementara konsep Christian Education mencakup 'semua bentuk pelayanan pendidikan dan atau pembinaan yang harus dilakukan oleh gereja sebagai upaya untuk memperlengkapi dan membina warganya, dari semua tingkat usia, agar mempunyai pengetahuan, pengertian serta
} 
Gereja dan Sekolah. Pada ranah Gereja, Pendidikan Kristiani (PK) seringkali diidentikkan dengan pengajaran kepada anak-anak. Sedangkan pada ranah sekolah, PK diidentikkan dengan mata pelajaran yang harus dipelajari oleh siswa/mahasiswa, yang berorientasi pada upaya mengisi tataran kognitif siswa/mahasiswa dan (secara sadar) mengabaikan domain afeksi dan psikomotorik sebagai sesuatu yang integral dalam pendidikan. Dengan melihat polarisasi yang terjadi ini, saya berargumentasi bahwa polarisasi yang mengemuka antara pelaksanaan PK di sekolah dan pelaksanaan PK di gereja dapat diatasi karena baik sekolah maupun gereja adalah learning spaces bagi PK. Tulisan ini dibagi atas tiga bagian. Bagian pertama akan memperlihatkan beberapa kesalahpahaman terhadap PK dalam konteks sekolah dan gereja yang berujung pada polarisasi. Bagian kedua memperlihatkan pelaksanaan PK dalam konteks gereja dan sekolah di Indonesia pada masa kini. Berdasarkan penjelasan pada bagian kedua, maka bagian ketiga ini akan menawarkan sejumlah prinsip sebagai upaya menjembatani gap antara PK yang berlangsung di sekolah dan di gereja.

Kata-kata Kunci: Pendidikan kristiani, sekolah, gereja, polarisasi

\section{Pendahuluan: \\ Beberapa Kesalahpahaman tentang Pendidikan Kristiani dalam Konteks Sekolah dan Gereja}

Saya ingin memulai tulisan ini dengan menuturkan beberapa narasi yang berdasar pada pengalaman saya sebagai seorang yang menggeluti bidang PK.

\section{Narasi 1}

Peristiwa ini terjadi pada pertengahan Agustus 1997, ketika saya baru memulai perkuliahan di Sekolah Tinggi Teologi Jakarta (sekarang Sekolah Tinggi Filsafat Theologi Jakarta). Sore itu saya menghubungi ayah saya dan ingin berdiskusi dengan beliau

penghayatan yang layak dalam kehidupan sehari-hari sebagai orang Kristen di tengah masyarakat. Dalam Studi Institut PERSETIA di Malang (1996), diusulkan agar nama ini diganti menjadi Pendidikan Kristiani” (Hardjowasito, Aritonang, dan Sinaga 2002, xi). Hal ini juga yang menjadi salah satu alasan mengapa sejak awal tahun 2000, Sekolah Tinggi Filsafat Theologi Jakarta memutuskan untuk menggunakan terminologi Pendidikan Kristiani (PK) dan bukan lagi Pendidikan Agama Kristen (PAK) dalam rumpun mata kuliah-mata kuliah dan berbagai aspek yang terkait dengannya. 
tentang pilihan konsentrasi yang akan saya ambil. Pada saat itu, angkatan kami mengalami kurikulum baru, ada pembagian konsentrasi/peminatan studi: Pastoral, Sains Teologi, Pendidikan Agama Kristen, dan Musik Gereja. Saya berencana mengambil konsentrasi Pendidikan Agama Kristen. Ketika saya menyampaikan hal ini kepada ayah saya, responsnya adalah tidak setuju karena menurutnya jika saya mengambil konsentrasi ini maka saya akan menjadi guru agama, bukan pendeta, sesuai dengan yang saya cita-citakan. Bagi ayah saya, PAK identik dengan Guru Agama. Meskipun saya sudah memberikan penjelasan panjang lebar kepada beliau, tetap saja tidak boleh. Akhirnya, tanpa sepengetahuan beliau saya menggeluti bidang ini. Nanti setelah lulus sarjana, saya baru menyampaikan hal ini kepada beliau.

\section{Narasi 2}

Cerita kedua ini terjadi selama masa perkuliahan saya di strata satu. Setiap kali saya menyebutkan bahwa bidang konsentrasi saya adalah PAK, semua orang-baik di kampus maupun di gereja-memberi komentar yang sama kepada saya: "Wah, pasti hebat yah dalam mengajar anak-anak di Sekolah Minggu. Wah pasti hebat yah dalam memikirkan kegiatan-kegiatan Sekolah Minggu. Boleh dong kami tanya-tanya kalau kami kesusahan dalam mengajar di anak-anak Sekolah Minggu."

\section{Narasi 3}

Kisah ini terjadi pada saat saya melanjutkan studi magister (pada tahun 2005-2006) dan doktoral (pada tahun 2010-2014). Setiap kali saya menyampaikan bahwa bidang konsentrasi studi saya adalah PK, maka respons teman-teman dari bidang konsentrasi lain adalah: "Wah, kamu bakal cepat selesai studinya. PK kan gampang, tidak susah." Peristiwa yang lebih menyakitkan terjadi ketika saya sedang menyusun disertasi. Setiap kali saya menyampaikan progress penulisan disertasi, dengan enteng beberapa kawan dari bidang studi lain menganggap bahwa saya bisa segera selesai karena PK itu mudah, sesuatu yang sangat praktikal, tidak butuh analisis dan tidak perlu dibuat sulit. Bagi mereka, bidang konsentrasi mereka lebih sulit. Mereka lebih lama masa studinya karena memang bidang mereka tidak segampang PK. Beberapa kawan bahkan berkali-kali menegaskan bahwa wajar untuk mereka yang di luar bidang PK (praktika) membutuhkan waktu lebih lama untuk menyelesaikan 
studinya. Saya hanya bisa tersenyum miris setiap kali berhadapan dengan situasi ini.

Tiga narasi yang saya tuturkan di atas bisa saja sama dengan pengalaman orang lain, namun bisa juga berbeda. Saya secara sengaja menuturkan narasi-narasi ini untuk memperlihatkan bahwa sejak lama PK/PAK sebagai sebuah bidang studi/bidang kajian diperlakukan secara keliru. Pada narasi pertama, tampak kepada kita bahwa PK itu diidentikkan dengan profesi guru agama. Siapa yang belajar atau mendalami PK pasti akan menjadi guru agama. Baginya tidak tersedia ruang yang lain untuk mengembangkan diri. Tempat yang tersedia baginya untuk berkiprah hanya terbatas pada sekolah. Kalaupun dia dilibatkan dalam kegiatan gereja, posisinya adalah mendampingi persiapan para guru Sekolah Minggu atau pengajar katekisasi, tidak lebih dari itu. Pada narasi kedua, PK/PAK diidentikkan dengan anakanak, atau dalam ranah gereja, PK/PAK sama dengan Sekolah Minggu. Dengan demikian, mereka yang belajar PK/PAK dianggap sangat mumpuni dalam mengajar Sekolah Minggu dan semua urusan yang berkaitan dengan anak di gereja. Pada narasi ketiga, tampak jelas bahwa PK adalah sesuatu yang mudah (dari segi bobot keilmuan) dibandingkan dengan konsentrasi studi yang lain. PK sebagai sebuah kajian (dan bidang-bidang lain yang ada dalam rumpun praktika) dianggap lebih mudah dari bidang biblika, historika, dan sistematika. ${ }^{2}$ Akibatnya tidak heran jika para mahasiswa/i yang menggeluti bidang PK harus menerima label demikian. Pemikiran dan sikap seperti ini juga dialami oleh para mahasiswa di beberapa Sekolah Tinggi Teologi/Fakultas Teologi di Indonesia. Program Studi PAK (dan para mahasiswanya) seringkali dianggap dan diperlakukan secara tidak adil/berbeda dari para mahasiswa program studi teologi. Mereka dianggap sebagai kelompok kelas kesekian dalam komunitas.

\footnotetext{
${ }^{2}$ Konsep ini dikembangkan dari pemikiran Schleiermacher yang memahami bahwa teologi disusun berdasarkan tiga bagian penting, yaitu: (1) philosophical theology (root/murel), historical theology (body/korper), and practical theology (crown/krone). John Burkhart, "Schleiermacher's Vision for Theology," in Practical Theology, ed., Don Browning (San Francisco: Harper and Row, 1983), 42-57. Untuk menggambarkan susunan ini, Schleiermacher menggunakan gambar pohon dengan membacanya secara vertikal, mulai dari bawah ke atas: dari filosofi teologi (akar) ke historikal teologi (badan), dan berujung pada praktikal teologi (mahkota). Jadi, meskipun seseorang dapat memulai dengan bagian manapun, dan bagian-bagian itu benarbenar saling bergantung, "tatanan paling alami" adalah dari teologi filosofis, melalui teologi historis, ke teologi praktika.
} 


\section{Pendidikan Kristiani dalam Konteks Sekolah-sekolah (di Indonesia)}

Dalam konteks sekolah-sekolah di Indonesia, PK atau yang lebih dikenal dengan nama PAK identik dengan mata pelajaran (pada level TK sampai dengan SMA), mata kuliah (pada level perguruan tinggi) dan program studi (pada level universitas/sekolah tinggi). Sebagai sebuah mata pelajaran atau mata kuliah, pelaksanaan PAK di sekolah-sekolah/perguruan tinggi mengikuti standar nasional yang ditetapkan oleh pemerintah, mulai dari desain kurikulum, buku ajar yang dipakai, isi pembelajaran, metode pembelajaran, evaluasi, dan sebagainya. Kalaupun ada sekolah yang mendesain sendiri kurikulum (termasuk buku ajar), mereka tetap harus mengikuti standar isi yang ditetapkan oleh pemerintah dengan melakukan beberapa penyesuaian.

Para pengajar yang mengampu mata pelajaran PAK di sekolahsekolah umumnya adalah mereka yang memenuhi standar kualifikasi tertentu, minimal Sarjana Teologi atau Sarjana PAK (Pendidikan). Meskipun kita tidak bisa menutup mata terhadap realitas bahwa masih ada sekolah-sekolah yang tidak memiliki Guru PAK. Akibat dari ketidaktersediaan tenaga pengajar ini, maka beberapa alternatif yang diambil oleh sekolah dan ditawarkan kepada siswa adalah: (1) siswa diminta mengikuti kelas pendidikan agama yang ada guru agamanya, (2) siswa diajar oleh yang bukan guru agama, yang penting dia Kristen dan mau mengajar, atau (3) meminta nilai PAK dari gereja tempat siswa berjemaat. Penilaian tentu tidak dilakukan oleh pendeta, tetapi oleh guru Sekolah Minggu. Dan, biasanya, guru Sekolah Minggu kewalahan memberi penilaian karena standar yang dipakai oleh sekolah (formal) berbeda total dengan apa yang diberlakukan di Sekolah Minggu. Alhasil, guru Sekolah Minggu seringkali memberikan nilai yang bagus bagi siswa dengan alasan supaya tidak memalukan gereja asal mereka.

Pelaksanaan mata pelajaran PAK di sekolah mengacu pada sejumlah Peraturan Pemerintah dan Undang-Undang sebagai dasar hukum yang mengatur dengan tujuan-tujuan spesifik yang mau dicapai, diantaranya adalah:

- Undang-Undang Dasar Negara RI Tahun 1945, Pasal 29, ayat 1 dan 2.

- Undang-Undang Republik Indonesia, Nomor 20 Tahun 2003, tentang Sistem Pendidikan Nasional, Bab II tentang Dasar, Fungsi dan Tujuan, Pasal 2; Bab V tentang Peserta Didik, Pasal 12.

- Peraturan Pemerintah Republik Indonesia Nomor 55 Tahun 2007, tentang Pendidikan Agama dan Pendidikan Keagamaan. 
- Peraturan Menteri Agama Republik Indonesia Nomor 16 Tahun 2010, tentang Pendidikan Agama.

- Peraturan Menteri Agama RI Nomor 27 Tahun 2016 tentang Perubahan atas Peraturan Menteri Agama Nomor 7 Tahun 2012 tentang Pendidikan Keagamaan Kristen, Pasal 1.

Jika membaca secara cermat sejumlah peraturan dan UU di atas, tertulis secara jelas bahwa hak setiap warga negara adalah mendapatkan pendidikan agama. Tidak hanya itu, pendidikan agama tersebut dilaksanakan untuk memenuhi sejumlah tujuan mulia, misalnya sebagaimana disebutkan dalam Peraturan Pemerintah Republik Indonesia Nomor 55 Tahun 2007, Bab II, Pasal 2, tentang Pendidikan Agama dan Keagamaan berikut ini:

(1) Pendidikan agama berfungsi membentuk manusia Indonesia yang beriman dan bertakwa kepada Tuhan Yang Maha Esa serta berakhlak mulia dan mampu menjaga kedamaian dan kerukunan hubungan inter dan antarumat beragama.

(2) Pendidikan agama bertujuan untuk berkembangnya kemampuan peserta didik dalam memahami, menghayati, dan mengamalkan nilai-nilai agama yang menyerasikan penguasaannya dalam ilmu pengetahuan, teknologi dan seni.

Peraturan dan UU ini tidak hanya merumuskan tujuan, tetapi juga mengatur pelaksanaan pendidikan agama tersebut, dengan misalnya menyebutkan secara spesifik pilihan-pilihan metode yang bisa dipakai dalam proses pembelajaran sehingga rumusan tujuan bisa dicapai dan isi materi pembelajaran bisa disampaikan oleh guru kepada siswa dengan cara-cara yang tepat.

Jika mengikuti penjelasan di atas, kita melihat bahwa ada Kurikulum Nasional dengan sejumlah peraturan dan UU yang mengatur pelaksanaan pendidikan agama ini. Tentu kita berharap bahwa desain PAK di sekolah harusnya berjalan dengan baik. Namun faktanya di lapangan adalah kita masih menjumpai bahwa desaindesain PAK (sebagai sebuah mata pelajaran) lebih berorientasi pada upaya mentransfer sebanyak mungkin ilmu/pengetahuan semata. Hal ini terjadi karena pelaksanaan PAK di sekolah-sekolah masih dipahami sebagai upaya transfer knowledge semata. Seseorang dinilai cerdas jika ia mampu menghafal dan menuturkan kembali sejumlah pengetahuan (Alkitab dan ajaran-ajaran Kristen). Akibatnya PAK menjadi semacam upaya indoktrinasi yang dilakukan oleh guru kepada siswa. Apa yang dipelajari semata-mata dipahami sebagai sebuah pengetahuan saja, dan tidak berdampak banyak dalam kehidupan para siswa. Daniel Stefanus 
menjelaskan beberapa alasan mengapa Pendidikan Agama (Kristen) di sekolah dinilai telah gagal, antara lain (1) Pendidikan agama seringkali dipusatkan pada hal- hal yang sifatnya simbolik, ritualistik, dan legal formalistik, (2) Pendidikan agama cenderung bertumpu pada domain kognitif (intelektual) atau paling tidak hanya sampai pada tataran afektif (emosional) saja, (3) Pendidikan agama tidak berhasil meningkatkan etika dan moralitas peserta didik, (4) Desain pendidikan di Indonesia hanya dipahami sebagai sebuah ilmu dan bukan perilaku, (5) Cukup banyak orang tua yang menyerahkan urusan pendidikan agama kepada sekolah, dan (6) Pendidikan agama tampaknya cenderung bersifat eksklusif. ${ }^{3}$

Menurut saya, apa yang disampaikan oleh Stefanus masih kita rasakan sampai saat ini. PAK di sekolah menjadi sesuatu yang sangat legalistik dengan sejumlah aturan main yang harus dilakukan. PAK tidak lagi menjadi sesuatu yang menyenangkan dan menggairahkan, melainkan sesuatu yang menakutkan. PAK juga menjadi sesuatu yang sangat kognitif, dan sangat terbatas dalam menyentuh ranah afeksi dan psikomotorik. Oleh karena orientasinya masih pada ranah kognitif, maka selalu ada daftar panjang bahan hafalan di setiap pertemuan kelas. Siswa dipaksa menghafal dan mengingat sejumlah informasi tanpa ditolong untuk memahami terlebih dahulu apa yang dihafal dan diingat olehnya. Siswa tidak memiliki "ruang" yang memadai untuk bertanyajawab dalam rangka memahami dan mendalami apa yang dipelajari olehnya. Akibatnya, pelajaran-pelajaran moral yang dipelajari hanya sampai pada level pengetahuan moral dan tidak tersedia ruang bagi upaya untuk mengembangkan perasaan moral dan tindakan moral. ${ }^{4}$ Akibatnya, kita terus mempertanyakan apa fungsi pelajaran agama di sekolah jika tindak kejahatan dan berbagai pelanggaran moral terus terjadi tanpa henti.

Selanjutnya, pola-pola pengajaran yang masih didominasi oleh guru (meskipun desain kurikulum sudah berganti berkali-kali) tidak

3 Daniel Stefanus, Pendidikan Agama Kristen Kemajemukan (Bandung: Bina Media Indonesia, 2009), 91.

4 Pengetahuan moral, perasaan moral, tindakan moral adalah komponen karakter yang baik yang diperkenalkan oleh Thomas Lickona. Thomas Lickona, Mendidik untuk. Membentuk Karakter: Bagaimana Sekolah dapat Mengajarkan Sikap Hormat dan Tanggung Jawab (Jakarta: Bumi Aksara, 2013), 84. Menurut Lickona, ketiga komponen ini tidak berfungsi secara terpisah tetapi saling terkait satu dengan yang lain. Pengetahuan moral mencakup aspek kesadaran moral, mengetahui nilai moral, penentuan perspektif, pemikiran moral, pengambilan keputusan dan pengetahuan pribadi; perasaan moral sebagai dimensi emosional dari karakter mencakup aspek hati nurani, harga diri, empati, mencintai hal yang baik, pengendalian diri, dan kerendahan hati; tindakan moral sebagai hasil dari pengetahuan dan perasaan tampak melalui kompetensi, keinginan, dan kebiasaan. Ibid., 85-101. 
membuka ruang yang memadai bagi siswa untuk mengeksplorasi pengetahuan dengan cara-cara yang ramah terhadap siswa. Kita berharap dengan terjadinya perubahan atas kurikulum di negeri ini, ada semacam angin segar bagi sekolah (khususnya para pendidik) untuk melakukan eksplorasi secara maksimal sehingga PAK sebagai sebuah mata pelajaran tidak sekadar sebagai sebuah lahan indoktrinasi yang dilakukan oleh guru kepada para siswa.

Berdasarkan realitas yang dipaparkan di atas, maka kita perlu meninjau ulang pelaksanaan PAK di sekolah. Menurut saya, hal pertama yang perlu dilakukan adalah memahami bahwa PAK bukan semata-mata sebuah ladang indoktrinasi, baik terhadap siswa Kristen ataupun "sarana" penginjilan bagi yang non-Kristen. PAK juga bukan semata-mata sebuah mata pelajaran sehingga aktivitas "transfer ilmu" yang lebih mendominasi. Pertanyaan penting yang pernah diajukan oleh Jedida T. Posumah-Santosa beberapa tahun lalu yang baik juga untuk saya perdengarkan kembali dalam tulisan ini adalah, "PAK sebagai satu bidang studi atau asuhan iman Kristen?"5 Pertanyaan Posumah-Santosa ini setidaknya mau memperlihatkan kepada kita dimensi lain dari pelaksanaan PK/PAK di sekolah yang seyogianya tidak hanya dipahami semata-mata sebagai sebuah mata pelajaran saja. Asuhan iman Kristen yang dimaksudkan oleh Posumah-Santosa adalah upaya mengajarkan "Injil yang senantiasa bersifat mengajar, mengubah, dan memanusiakan manusia" sehingga pelaksanaan PAK di sekolah "bukan hanya mengarah pada penguasaan pengetahuan dan keterampilan, tetapi juga kepada perilaku dan kepribadian yang matang" Jika demikian, maka PAK di sekolah tidak lagi dipahami hanya semata-mata sebagai sebuah mata pelajaran, tetapi dia terintegrasi dalam desain pendidikan dan menjiwai derap langkah pembelajaran di sekolah. Jika ia dibatasi pada lingkup mata pelajaran saja, maka segala sesuatu yang terjadi di dalamnya akan dipertimbangkan hanya sebagai upaya untuk mencapai standar pendidikan tertentu, dan ketika standar tersebut tercapai maka selesailah sudah segala proses pendidikan tersebut.

Friedrich Schweitzer menjelaskan bahwa ada empat pertanyaan penting yang perlu dipertimbangkan ketika kita berbicara tentang Pendidikan Kristiani di sekolah, antara lain: (1) Apakah agama termasuk dalam pendidikan, dan jika ya, dalam arti apa? (2) Haruskah pendidikan agama berlangsung di sekolah atau hanya di tempat-tempat

5 Jedida T. Posumah-Santosa, "Pendidikan Agama Kristen di Sekolah: Suatu Bidang Studi atau Asuhan Iman Kristen?” dalam Ajarlah Mereka Melakukan: Kumpulan Karangan seputar Pendidikan Agama Kristen, ed., Andar Ismail (Jakarta: BPK Gunung Mulia, 1998), 159.

6 Ibid., 156. 
lain? (3) Haruskah pendidikan agama diselenggarakan secara tersendiri sebagai sebuah subjek (pelajaran) ataukah ada cara-cara lain seperti memperlakukan topik-topik keagamaan di semua mata pelajaran yang disukai? dan (4) Dapatkah pendidikan agama dibatasi pada mata pelajaran tertentu atau haruskah sekolah mengintegrasikannya ke dalam subjek-subjek yang lain? ${ }^{7}$ Empat pertanyaan Schweitzer ini mau mengajak kita untuk mempertanyakan esensi hadirnya PK/PAK di sekolah. Apakah PK/PAK harus dibatasi pada sebuah mata pelajaran tertentu atau terintegrasi juga dalam derap pembelajaran di sekolah?

Ketika mempercakapkan cakupan ini, maka peringatan dari Randolph Crump Miller perlu diperhatikan dengan saksama. Miller menjelaskan bahaya yang harus kita antisipasi ketika sekolah (milik pemerintah) menyelenggarakan pendikan agama. Hal itu dikarenakan "sekolah dari sebuah negara selalu merefleksikan politik dan model bangsa tersebut" Itu sebabnya Miller menyarankan bahwa ketika sekolah menyelenggarakan pendidikan, termasuk PK/PAK, maka sekolah harus memastikan bahwa ia siap mendukung keberlangsungan pendidikan dan tidak ada upaya-upaya yang berbau sektarian dalam penyelenggaraan pendidikan. ${ }^{9}$ Pemikiran Miller ini ada benarnya ketika kita melihat dari perspektif kurikulum. Kurikulum pendidikan, untuk mata pelajaran apapun, selalu memiliki tendensi untuk mengikuti atau didominasi oleh ideologi tertentu dari desainer kurikulum atau para penulis. Lebih lanjut Miller menegaskan bahwa pendidikan agama di sekolah memainkan peranan penting karena kualitas kehidupan di dalam sekolah adalah sesuatu yang krusial: pendidikan agama berfungsi untuk membentuk perilaku-perilaku religius sesuai dengan desain kurikulum yang dibuat. ${ }^{10}$

Bukan hanya pengaruh negara atas pelaksanaan PK/PAK di sekolah yang perlu diperhatikan, Posumah-Santosa juga memberikan pertimbangan untuk muatan PK/PAK di sekolah yang berada di bawah asuhan gereja/denominasi tertentu. Menurutnya dibutuhkan "pengajaran yang bersifat lebih oikumenis, jangan mengutamakan ajaran satu aliran atau denominasi saja, atau mengajak siswa menjadi anggota gereja tertentu." "11 Sederhananya, PK/PAK di sekolah harus lebih bersifat ekumenis.

${ }^{7}$ Friedrich Schweitzer, "Religious Education as a Task of the School," in Basics of Religious Education, eds., Martin Rothgangel, et al. (Gottingen: V \& R Unipress, 2014), 81.

8 Randolph Crump Miller, Educating for Christian Living (New Jersey: Prentice Hall, 1959), 106.

9 Ibid., 107.

10 Ibid., 120

11 Posumah-Santosa, "Pendidikan Agama Kristen di Sekolah," 161. 
Jika menelisik lebih jauh pada penjelasan di atas, kita melihat bahwa pelaksanaan PK/PAK di sekolah lebih didominasi oleh berbagai aturan yang berlaku pada level pemerintahan. Gereja seolaholah seperti kehilangan genggamannya. Bahkan untuk beberapa sekolah yang berada di bawah naungan gereja, tidak terlihat jelas campur tangan gereja di dalamnya, terlebih dalam hal mendesain materi-materi pelajaran (kurikulum) bagi para siswa.

\section{Pendidikan Kristiani dalam Konteks Gereja (di Indonesia)}

Selain sekolah, Gereja juga menjadi lokus yang tidak kalah penting bagi pelaksanaan PK. Dalam konteks bergereja kita harus mengakui bahwa pelaksanaan PK lebih diprioritaskan pada anak-anak dan remaja. Dalam bukunya yang berjudul Fashion Me a People, Maria Harris mengidentifikasi dua kesalahpahaman tentang PK di gereja. Kesalahpahaman yang pertama adalah PK identik dengan anak-anak. ${ }^{12}$ Akibatnya, ketika kita merancang desain pendidikan untuk kategori usia yang lain, maka perlu ada catatan yang spesifik tentang peruntukkan desain pendidikan ini, misalnya PK untuk pemuda atau orang dewasa. Hal ini terjadi karena cara berpikir yang keliru bahwa "PK itu sama dengan pendidikan untuk anak-anak" melekat kuat dalam ingatan dan mewujud dalam tingkah laku. Kesalahpahaman yang kedua adalah PK diidentikkan dengan urusan persekolahan. ${ }^{13}$ Kesalahpahaman yang kedua ini membuat banyak orang menyamakan pendidikan yang diselenggarakan di gereja dengan setting sekolah formal, sehingga kapur dan papan tulis menjadi teman setia dalam mengajar. Harris mencoba untuk secara jeli memetakan kesalahpahaman ini dan menyertakan kerangka berpikir yang baru sebagaimana tergambar dalam bagan berikut ini: ${ }^{14}$

\begin{tabular}{|c|c|c|}
\hline Empat & Sebelumnya & Saat Ini \\
Area & & \\
\hline & & \\
\hline
\end{tabular}

12 Maria Harris, Fashion Me a People: Curriculum in the Church (Louisville:

Westminster John Knox Press, 1989), 39.

13 Ibid., 36.

14 Ibid., 46. 


\begin{tabular}{|c|c|c|}
\hline Agen & $\begin{array}{l}\text { PK dilaksanakan oleh orang- } \\
\text { orang tertentu, misalnya: } \\
\text { pendeta, guru Sekolah } \\
\text { Minggu, penatua, diaken, dsb. }\end{array}$ & $\begin{array}{l}\text { PK dilaksanakan oleh } \\
\text { seluruh } \\
\text { anggota komunitas }\end{array}$ \\
\hline Aktivitas & $\begin{array}{l}\text { PK dipahami sebagai proses } \\
\text { memberi instruksi atau } \\
\text { indoktrinasi, khususnya } \\
\text { doktrin-doktrin keagamaan. }\end{array}$ & $\begin{array}{l}\text { PK dipahami sebagai proses } \\
\text { mendidik dan } \\
\text { memberdayakan. }\end{array}$ \\
\hline Partisipan & Anak & Seluruh anggota komunitas \\
\hline Petunjuk & $\begin{array}{l}\text { Mengetahui tata aturan yang } \\
\text { berlaku dan mematuhinya. }\end{array}$ & $\begin{array}{l}\text { Memperlengkapi orang untuk } \\
\text { mengetahui apa yang } \\
\text { sementara terjadi (termasuk } \\
\text { di masyarakat) dan berjuang } \\
\text { untuk melakukannya. }\end{array}$ \\
\hline
\end{tabular}

Dalam konteks bergereja di Indonesia, kesalahpahaman ini pernah menguat di gereja-gereja. Dampak positifnya adalah ketersediaan bahan ajar bagi anak dan remaja sangat banyak dibandingkan dengan kategori usia lainnya, apalagi untuk orang dewasa. ${ }^{15}$ Namun demikian, secara prinsip, PK tidak hanya identik

${ }^{15}$ Lih. Justitia Vox Dei Hattu, "Crossing the Bridge: Christian Education for Enhancing Adult Meaning-Making Oriented for Transformation in the Contemporary Context of Indonesia," Ph.D. diss. (Yonsei University, 2014), 39. 
dengan pelayanan anak atau aktivitas Sekolah Minggu. PK mencakup seluruh aktivitas belajar-mengajar di gereja. Semua upaya gereja untuk mendidik dan mengajar umat harus dilihat sebagai bagian yang utuh dari PK. Itu sebabnya mengapa kita perlu memberi perhatian yang sama pada semua upaya mendidik berbagai kelompok usia di gereja, termasuk kelas-kelas katekisasi-baik kelas katekisasi untuk peneguhan sidi maupun untuk persiapan dan selama masa perkawinan-kelompok Penelaahan Alkitab, khotbah, dan lain sebagainya. Pelaksanaan PK di gereja, pada berbagai konteksnya, secara sederhana bertujuan untuk pewarisan nilai-nilai iman Kristen dari generasi ke generasi. Pewarisan nilai-nilai iman ini mengambil bentuk yang berbeda-beda sebagaimana disebutkan di atas. Isi dari proses pewarisan itu lebih banyak ditentukan oleh gereja/sinode setempat yang umumnya menyesuaikan dengan kebutuhan konteks, pada tataran lokal maupun global.

\section{Menjembatani Perbedaan, Menuju Tanggung Jawab Bersama Gereja dan Sekolah atas Pendidikan Kristiani}

Berdasarkan uraian tentang pelaksanaan Pendidikan Kristiani di sekolah dan gereja, maka menurut saya ada sejumlah titik persamaan namun juga perbedaan. Berikut adalah pemetaan saya atas masingmasing konteks yang sudah saya uraikan di atas: ${ }^{16}$

\begin{tabular}{|c|c|c|}
\hline $\begin{array}{c}\text { Isu-isu } \\
\text { Pedagogis }\end{array}$ & Sekolah & Gereja \\
\hline Tujuan & $\begin{array}{l}\text { Cenderung mengikuti } \\
\text { rumusan tujuan } \\
\text { pendidikan dari } \\
\text { pemerintah/sekolah } \\
\text { setempat }\end{array}$ & $\begin{array}{l}\text { Mewariskan iman } \\
\text { Kristen } \\
\text { dari satu generasi ke } \\
\text { generasi berikutnya }\end{array}$ \\
\hline
\end{tabular}

Ketersediaan ini tidak berarti bahwa gereja memberi perhatian penuh terhadap anak, sebab sampai sekarang pun ada cukup banyak gereja yang tidak terlalu memberi perhatian besar kepada anak dalam pelayanannya. Lihat misalnya, penjelasan F.C. Lewier, "Pendidikan Agama Kristen yang Partisipatif dan Transformatif dalam Konteks Indonesia," dalam Memperlengkapi bagi Pelayanan dan Pertumbuhan: Kumpulan Karangan Pendidikan Kristiani dalam Rangka Penghormatan kepada Pdt. Prof. Dr. Robert R. Boeblke, eds., Kadarmanto Hardjowasito, Jan S. Aritonang, dan Martin L. Sinaga (Jakarta: BPK Gunung Mulia, 2002.)

16 Bdk. Uta Pohl-Patalong, "Learning in School and in the Congregation: A Comparison with regard to Conformation Work,", in Basics of Religious Education, eds., Martin Rothgangel, et.al. (Gottingen: V \& R Unipress, 2014), 118-119. 


\begin{tabular}{|c|c|c|}
\hline Konteks & $\begin{array}{l}\text { Sekolah-dengan } \\
\text { terbatas pada ruang- } \\
\text { ruang kelas formal }\end{array}$ & $\begin{array}{c}\text { Gereja-dengan } \\
\text { mencakup beberapa } \\
\text { kelompok, antara lain: } \\
\text { Sekolah Minggu, } \\
\text { kelompok remaja dan } \\
\text { pemuda, kelompok } \\
\text { dewasa, kelas-kelas } \\
\text { katekisasi (untuk } \\
\text { peneguhan sidi dan } \\
\text { perkawinan), ibadah, } \\
\text { pastoral konseling, dsb. }\end{array}$ \\
\hline \multirow[t]{2}{*}{ Partisipan } & $\begin{array}{c}\text { Pendidik: } \\
\text { Guru yang memenuhi } \\
\text { kualifikasi standar } \\
\text { tertentu yang sudah } \\
\text { ditetapkan } \\
\text { oleh pemerintah/sekolah }\end{array}$ & $\begin{array}{c}\text { Pendidik: } \\
\text { Awalnya dibatasi pada } \\
\text { orang-orang tertentu: } \\
\text { pendeta, guru Sekolah } \\
\text { Minggu, penatua, } \\
\text { diaken, dll. Sekarang } \\
\text { seluruh anggota } \\
\text { komunitas (warga } \\
\text { gereja) adalah pendidik }\end{array}$ \\
\hline & $\begin{array}{c}\text { Naradidik: } \\
\text { Anak, remaja dan } \\
\text { pemuda (usia 2-25 } \\
\text { tahun) }\end{array}$ & $\begin{array}{c}\text { Naradidik: } \\
\text { Semua warga jemaat, } \\
\text { dari } 0 \text { tahun sampai } \\
\text { dengan lanjut usia }\end{array}$ \\
\hline Kurikulum & $\begin{array}{l}\text { Ditulis/disiapkan oleh } \\
\text { Tim Kurikulum } \\
\text { Nasional dan berlaku } \\
\text { secara nasional dengan } \\
\text { penyesuaian pada } \\
\text { konteks lokal }\end{array}$ & $\begin{array}{c}\text { Tersedia hanya untuk } \\
\text { beberapa kategori usia } \\
\text { saja, misalnya untuk } \\
\text { anak, remaja, dan } \\
\text { pemuda. Sedangkan } \\
\text { untuk beberapa } \\
\text { kategori usia yang lain, } \\
\text { belum tersedia secara } \\
\text { memadai, sehingga } \\
\text { gereja-gereja lokal } \\
\text { harus } \\
\text { mengupayakannya }\end{array}$ \\
\hline
\end{tabular}




\begin{tabular}{|c|c|c|}
\hline & & $\begin{array}{c}\text { dengan segala } \\
\text { keterbatasan mereka. }\end{array}$ \\
\hline $\begin{array}{l}\text { Konten } \\
\text { (Materi) }\end{array}$ & $\begin{array}{l}\text { Menyesuaikan dengan } \\
\text { standar isi dari } \\
\text { pemerintah. Biasanya } \\
\text { fokus pada pengetahuan } \\
\text { Alkitab, pendidikan } \\
\text { karakter dan bagaimana } \\
\text { menerapkannya dalam } \\
\text { kehidupan sehari-hari. } \\
\text { Oleh karena terbatas } \\
\text { pada isu-isu tertentu dan } \\
\text { agak lambat dalam } \\
\text { mengakomodasi } \\
\text { kebutuhan-kebutuhan } \\
\text { yang sifatnya urgent dan } \\
\text { kontekstual. Yang bisa } \\
\text { dilakukan hanyalah } \\
\text { dikaitkan dengan } \\
\text { pelajaran-pelajaran } \\
\text { tertentu yang terkait, } \\
\text { tetapi tergantung pada } \\
\text { waktu pembelajarannya. }\end{array}$ & $\begin{array}{l}\text { Menyesuaikan dengan } \\
\text { tema tahunan atau } \\
\text { lima tahunan sinode. } \\
\text { Fokus pada isi Alkitab, } \\
\text { nilai-nilai hidup, } \\
\text { karakter, sejarah dan } \\
\text { tradisi kekristenan, isu- } \\
\text { isu sosial-kemanusiaan, } \\
\text { dll. } \\
\text { Isu-isu aktual bisa } \\
\text { dengan } \\
\text { segera diintegrasikan } \\
\text { ke dalam bahan ajar. }\end{array}$ \\
\hline Metode & $\begin{array}{c}\text { Secara tertulis (dalam } \\
\text { bahan ajar) lebih } \\
\text { bervariasi karena } \\
\text { mengikuti standar } \\
\text { pembelajaran yang sudah } \\
\text { ditetapkan oleh } \\
\text { pemerintah, namun } \\
\text { dalam praktiknya bisa } \\
\text { sangat monoton karena } \\
\text { juga mempertimbangkan } \\
\text { potensi dan kemampuan } \\
\text { guru yang mengajar, } \\
\text { termasuk } \\
\text { para siswa. }\end{array}$ & $\begin{array}{c}\text { Cenderung satu arah } \\
\text { dan masih bersifat } \\
\text { indoktrinatif }\end{array}$ \\
\hline
\end{tabular}

Dari penjelasan di atas, maka saya mencoba mengonstruksi sebuah "jembatan" relasi yang harmonis antara sekolah dan gereja yang 
adalah dua basis utama pelaksanaan PK dalam beberapa pokok pemikiran berikut ini.

Pertama, PK dalam ragam konteksnya, menurut saya, pertamatama harus berorientasi pada upaya memanusiakan manusia. Uraian sebelumnya memperlihatkan kepada kita bahwa pola-pola pengajaran yang indoktrinatif masih cukup mendominasi wajah PK/PAK, baik pada ranah sekolah maupun gereja. Proses memanusiakan ini tidak hanya terjadi dalam pola relasi pendidik kepada naradidik, tetapi juga pendidik terhadap dirinya sendiri. Sebab esensi dari sebuah pendidikan, bukanlah semata-mata terletak pada berbobot atau tidaknya materi yang diajarkan, serta efektif atau tidak metode yang dipakai, melainkan terletak juga pada nilai/wajah seorang manusia (baik pendidik, maupun naradidik) yang terlibat dalam proses pendidikan tersebut. Cara kita memandang orang lain (dan diri kita) akan menentukan pola pikir, pola rasa, dan pola laku kita terhadapnya. Realitas pendidikan di Indonesia menunjukkan kepada kita bahwa Guru PAK di sekolah lebih banyak disibukkan dengan tugas-tugas administratif mengajar, daripada mengajar dan berinteraksi dengan para siswa. Akibatnya, para guru menjadi lelah dengan tugas-tugas administratif, dan mengajar sebagai tanggung jawab utama seringkali tidak menjadi prioritas utama.

Pokok pikiran yang pertama ini menjadi penting untuk dipercakapkan karena kita sementara (atau akan segera) berada di era Revolusi Industri 4.0 yang dampaknya, jika tidak segera diantisipasi oleh sekolah maupun gereja, akan segera menggerus nilai seorang manusia. Mungkin kita perlu belajar dari dunia pemasaran tentang caracara mereka memperlakukan seorang manusia. Hermawan Kartajaya memetakan tiga tren yang terjadi dalam dunia pemasaran dengan adanya perubahan (teknologi) informasi, yaitu (1) dari vertikal menjadi horizontal, (2) dari eksklusif menjadi inklusif, dan (3) dari individual menjadi sosial ${ }^{17}$ Dalam konteks dunia pemasaran, dari vertikal menjadi horizontal menunjuk kepada posisi pemasar dan konsumen yang bergeser dari pola yang top down (posisi top adalah pemasar, dan posisi down adalah konsumen) menjadi setara. ${ }^{18}$ Dari eksklusif menjadi inklusif menunjuk kepada akses informasi yang dulunya hanya dikuasai oleh kelompok tertentu (dalam hal ini pemasar), kini dikuasai bebas oleh konsumen sehingga konsumen menjadi orang-orang yang cerdas yang bisa mencari dan mengakses informasi secara utuh. ${ }^{19}$ Dari individual menjadi sosial menunjuk kepada model atau pola relasi (pemasar) yang

17 Hermawan Kartajaya, Citizen 4.0: Menjejakkan Prinsip-Prinsip Pemasaran Humanis di Era Digital (Jakarta: Gramedia, 2019), 32-34.

18 Ibid., 32-33.

19 Ibid., 33-34. 
terbuka, bersahabat, dan mau berinteraksi dengan konsumen. ${ }^{20}$ Tiga tren ini menjadi bahan pembanding bagi kita dalam upaya memanusiakan manusia dalam dunia pendidikan. Saya melihat setidaknya ada tiga implikasi penting darinya, yaitu (1) posisi pendidik dan naradidik bergeser dari yang top down menjadi egaliter, (2) pengetahuan tidak lagi dimiliki oleh pendidik tetapi juga oleh naradidik, dan (3) pola relasi yang terbangun adalah pola relasi yang terbuka terhadap berbagai masukan dan pertimbangan serta bersahabat. Tiga implikasi ini sedikit banyak akan tergambar juga dalam pokok pemikiran kedua hingga kelima di bawah ini.

Kedua, mengajar (dan belajar), sebagai sebuah aktivitas penting dalam PK, baik di sekolah maupun gereja, harus dilihat bukan sematamata sebagai sebuah proses mentransfer ilmu, atau sebuah proses inisiasi ke dalam sebuah komunitas, atau upaya meneruskan tradisi (Kristen) ke generasi berikutnya, atau bahkan sebagai upaya untuk mengajarkan seseorang tentang Alkitab dan bagaimana menerapkan teks-teks Alkitab itu dalam kehidupannya sehari-hari saja, melainkan juga sebagai sebuah upaya memaknai ulang, mempertanyakan, menganalisis apa yang dipelajari, dan bahkan menolak apa yang tidak sesuai. ${ }^{21}$ Pada titik ini, saya kira kita membutuhkan kerendahan hati, kemampuan berpikir kritis, dan model berkomunikasi (mengajar) yang dialogis, yang kemudian bermuara pada transformasi diri maupun komunitas. Kerendahan hati menolong kita, pendidik dan naradidik, memahami bahwa kita hanya satu di antara sekian banyak pembelajar lain yang tahu tentang sesuatu, dan bukan satu-satunya yang paling tahu. Berpikir kritis menolong untuk mengkritisi pengetahuan yang kita miliki sebelumnya dan keberanian untuk mau membuka diri terhadap berbagai informasi dan pengetahuan serta pengalaman yang baru. Kemampuan berpikir kritis ini, menurut saya, juga menolong pendidik dan naradidik, untuk berani mengatakan pendapatnya tanpa dibayangbayangi oleh pemikiran/penilaian orang lain atas dirinya. Percakapanpercakapan dialogis membuka ruang bagi runtuhnya pola-pola relasi yang top-down, subjek-objek, yang dipelihara dengan baik oleh model indoktrinasi. Transformasi sebagai muara dari proses pembelajaran membuka ruang bagi dihasilkannya kesadaran-kesadaran baru atas diri maupun komunitas.

Ketiga, sekolah dan gereja adalah dua di antara sekian banyak learning spaces bagi pelaksanaan PK. Oleh karenanya, baik sekolah maupun gereja perlu saling melirik atau bahkan saling menggenggam satu dengan yang lain, sehingga jurang perbedaan itu semakin sempit dan upaya-upaya kerja bersama itu semakin terbuka lebar. Untuk

\footnotetext{
20 Ibid., 34.

${ }^{21}$ Harris, Fashion Me a People, 116.
} 
gereja-gereja yang mendirikan sekolah, kerjasama dan bentuk perhatian yang diberikan oleh gereja kepada sekolah tidak boleh dilihat sematamata sebagai sarana pelestarian (eksistensi) gereja, melainkan harus dimaknai sebagai upaya menjaga dan memelihara individu-individu yang ada di sekolah, termasuk melindungi dan memenuhi hak-hak mereka. ${ }^{22}$ Selanjutnya, meskipun sekolah dan gereja menjadi learning spaces bagi pelaksanaan PK, namun tidak berarti pelaksanaan pendidikan itu hanya berlangsung dalam "tembok-tembok" gereja dan sekolah, melainkan harus melampaui tembok-tembok tersebut. Desain PK harus membuka ruang bagi keterlibatan para partisipan di dalam dan di luar sekolah dan gereja sehingga tidak banyak yang hanya "jago kandang" atau "jago dalam tempurung" sekolah dan gereja. Keterlibatan langsung dalam masyarakat dan beragam learning spaces yang lain akan memperkaya wawasan berpikir sekaligus membentuk identitas para pelaku PK. Contoh sederhana untuk hal ini adalah keterlibatan para partisipan dalam berbagai aksi sosial (kemanusiaan) untuk mereka yang membutuhkan pertolongan; kampanye damai antikekerasan terhadap perempuan, anak dan mereka yang terpinggirkan oleh berbagai situasi sosial; keikutsertaan dalam forum atau kelompok dialog antar umat beragama, seperti Peace Train Indonesia yang diperuntukkan untuk kaum muda lintas agama dan sebagainya. ${ }^{23}$

Keempat, kerja bersama antara gereja dan sekolah mewujud salah satunya melalui upaya berbagi tanggung jawab (sharing responsibility). Berbagi tanggung jawab ini tidak dimaknai sebagai upaya mengkotak-kotakan atau membuat penegasan yang jelas tentang apa yang menjadi tanggung jawab gereja dan apa yang menjadi tanggung jawab sekolah. Sebab keduanya (bahkan ketiganya, bersama dengan keluarga) harus saling melengkapi satu dengan yang lain. Apa yang diajarkan/dipelajari di sekolah harus mendapatkan penguatan di gereja dan di keluarga, dan begitu juga sebaliknya, supaya pembelajar (khususnya anak-anak) tidak terus-menerus mengalami konflik batin karena perbedaan-perbedaan yang didapatkan selama ia belajar pada berbagai konteks tersebut. Menurut Miller, setidaknya ada tiga alasan mengapa perlu ada relasi yang baik antara gereja (dalam hal ini jemaat lokal) dengan sekolah:

22 Michael Wermke, "Religion in School Outside Religious Education," in Basics of Religious Education, eds., Martin Rothgangel, et.al. (Gottingen: V \& R Unipress, 2014), 101.

23 Justitia Vox Dei Hattu, Mewarga dengan Hati: Pembelajaran Transformatif sebagai Respons Pedagogis Kristiani terhadap Tantangan Pendidikan Kewarganegaraan dalam Konteks Indonesia Masa Kini (Jakarta: BPK Gunung Mulia, 2018), 40-41. 
(a) Kita perlu mengenal nilai-nilai yang melekat atau diwariskan dalam pengajaran di sekolah publik maupun privat. ${ }^{24}$ Misalnya nilai-nilai luhur demokrasi yang diajarkan dan karakter Kristen yang ditanamkan harus dipastikan bahwa ia memiliki akar yang kuat dalam tradisi kekristenan dan juga dalam tradisi agamaagama lain.

(b) Pada waktu-waktu tertentu, gereja akan melakukan program yang membutuhkan tenaga-tenaga ahli dan orang-orang yang berkompeten yang bisa gereja dapatkan dari sekolah, dan sebaliknya. $^{25}$

(c) Gereja menolong "mengawasi” ajaran-ajaran yang diajarkan di sekolah-sekolah sebab bisa saja yang diajarkan itu adalah sesuatu yang bertentangan dengan nilai keagamaan yang umum berlaku dan diakui di sekolah. ${ }^{26} \mathrm{Hal}$ ini juga terjadi sebaliknya di gereja. Setiap orang yang datang ke gereja membawa serta pengalaman-pengalaman dan ajaran-ajaran yang mereka terima di sekolah. Pengalaman-pengalaman ini perlu untuk dipercakapkan, diinterpretasi, dikritisi, dan dievaluasi bersama, sehingga ruang-ruang untuk hal ini perlu tersedia secara memadai, baik di sekolah maupun di gereja.

Kelima, materi pembelajaran PK tidak hanya mengakomodasi isi Alkitab dan doktrin/ajaran Kristen, tetapi ia juga membuka diri pada cerita dan pengalaman bidup para partisipan yang mengambil bagian dalam proses pembelajaran. Partisipan (umumnya naradidik) menjadi "expert resources" bagi sesamanya. ${ }^{27}$ Jika ruang ini terbuka lebar, maka menurut saya, sekolah dan juga gereja sementara menolong para warga jemaat untuk beranjak dari pola pendidikan yang hanya menadahkan tangan (meminta) kepada pola pendidikan yang mengulurkan tangan (memberi). Selain pengalaman para partisipan, isu-isu aktual yang berkembang di gereja atau masyarakat, seperti pluralitas suku dan agama, bagaimana hidup berdampingan dengan denominasi atau agama lain, gender dan kesetaraan, kemiskinan, keadilan sosial, dan sebagainya, bisa diakomodasi untuk masuk menjadi materi pembelajaran.

Terkait keluasan cakupan materi PK ini, Sara Little misalnya, menjelaskan bahwa PK yang berlangsung di gereja (dan saya kira usul

\footnotetext{
24 Miller, Educating for Christian Living, 148.

25 Miller, Educating for Christian Living, 149.

26 Miller, Educating for Christian Living, 150. Lihat juga Pohl-Patalong, "Learning in School and in the Congregation," 116.

27 Ben Freudenburg \& Rick Lawrence, The Family Friendly Church (Loveland, Colorado: Group, 1998), 62.
} 
yang sama bisa dikembangkan di sekolah dengan melakukan penyesuaian pada beberapa hal) setidaknya mencakup lima dimensi yang integratif, yaitu kerygma (memproklamasikan kebangkitan Yesus), didache (aktivitas belajar dan mengajar), leiturgia (komunitas yang berdoa dan beribadah), koinonia (persekutuan), dan diakonia (memperhatikan yang membutuhkan). ${ }^{28}$ Jika ini yang terjadi, maka PK tidak lagi dibatasi sebagai sebuah mata pelajaran saja, termasuk dalam lingkup kelas-kelas formal saja, sebab PK juga terjadi dalam berbagai bentuk aktivitas yang lain, baik di sekolah maupun gereja.

Senada dengan Little, meski dalam bentuk yang berbeda, Jack L. Seymour mencoba mengelompokkan empat ragam pendekatan terhadap PK, yakni social transformation (transformasi sosial), faith community (komunitas iman), spiritual growth (pertumbuhan spiritualitas), dan religious instruction (instruksi religius). ${ }^{29}$ Karen B. Tye melihat empat pendekatan ini sebagai upaya untuk memahami dan mendefinisikan serta menentukan isi dari PK itu sendiri. ${ }^{30}$ Dari perspektif transformasi sosial, PK yang diselenggarakan berorientasi pada upaya untuk mengembangkan kemampuan berpikir dan berefleksi kritis, serta mendorong partisipan untuk terlibat dalam aksi-aksi sosial kemanusiaan. ${ }^{31}$ Dari perspektif komunitas iman, pendidikan terjadi melalui proses sosialisasi dan interaksi dengan anggota komunitas melalui beragam aktivitas gerejawi, seperti partisipasi dalam ibadah, bernyanyi dan berdoa bersama, kelompok tumbuh bersama, dan sebagainya. ${ }^{32}$ Selanjutnya, dari perspektif pertumbuhan spiritual, pendidikan dipahami sebagai proses untuk menolong pertumbuhan seseorang, secara moral, iman, spiritual, karakter, dan sebagainya. ${ }^{33}$ Terakhir, dari perspektif instruksi religius, pendidikan dipahami sebagai usaha sengaja dan terencana untuk mengajarkan pengetahuan

\footnotetext{
${ }^{28}$ Sara Little, To Set One's Heart: Belief and Teaching in the Church (Atlanta: John Knox Press, 1983), 16.

29 Jack L. Seymour, ed., Mapping Christian Education (Nashville: Abingdon Press, 1997), 21. Sebelumnya, Seymour bersama dengan Donald E. Miller juga menyunting buku sejenis di tahun 1982, berjudul Contemporary Approaches to Christian Education. Dalam buku ini, Seymour dan Miller bersama dengan beberapa pakar Pendidikan Kristiani lainnya mencoba memetakan lima pendekatan dalam Pendidikan Kristiani, yakni religious instruction, faith community, spiritual development, liberation, dan interpretation. Jack L. Seymour \& Donald E. Miller, eds., Contemporary Approaches to Christian Education (Nashville: Abingdon Press, 1982), 16.

30 Karen B. Tye, Basics Christian Education (Danvers, MA: Chalice Press, 2000) 10.

31 Seymour, Mapping Christian Education, 19; ibid., 12.

32 Seymour, Mapping Christian Education, 19; Tye, Basics Christian Education, 11.

33 Tye, Basics Christian Education, 11; Seymour, Mapping Christian Education, 
dan praktik hidup sebagai orang Kristen. Proses pengajaran ini tidak terjadi dalam bentuk-bentuk yang formal dan kaku, melainkan lebih dipahami sebagai sebuah homemaking, yakni sebuah kerja bersama anggota keluarga. ${ }^{34}$ Tentunya, setiap pendekatan ini dipakai dengan menyesuaikan pada kebutuhan konteks, sehingga ada pendekatan yang akan lebih dominan karena kebutuhan konteks mengharuskan demikian, dan ada pendekatan yang berfungsi melengkapi.

\section{Penutup}

Polarisasi Pendidikan Kristiani yang berlangsung di sekolah dan gereja terjadi karena pemahaman yang dangkal tentang apa itu Pendidikan Kristiani dan juga upaya untuk "mengurung" Pendidikan Kristiani pada satu wilayah tertentu saja. Padahal, ada keterkaitan yang erat antara pendidikan Kristiani di gereja dan di sekolah, dan keduanya memainkan fungsi saling melengkapi karena mereka pada konteksnya masing-masing memiliki kekhasannya.

\section{Tentang Penulis}

Justitia Vox Dei Hattu adalah dosen tetap bidang Pendidikan Kristiani di Sekolah Tinggi Filsafat Theologi (STFT) Jakarta.

\section{Daftar Pustaka}

Burkhart, John. "Schleiermacher's Vision for Theology." In Practical Theology. Ed., Don Browning, 42-57. San Francisco: Harper and Row, 1983.

Freudenburg, Ben \& Rick Lawrence. The Family Friendly Church. Loveland, Colorado: Group, 1998.

Hardjowasito, Kadarmanto, Jan S. Aritonang, dan Martin L. Sinaga, eds. Memperlengkapi bagi Pelayanan dan Pertumbuhan: Kumpulan Karangan Pendidikan Kristiani dalam Rangka Penghormatan kepada Pdt. Prof. Dr. Robert R. Boeblke. Jakarta: BPK Gunung Mulia, 2002.

Harris, Maria. Fashion Me a People: Curriculum in the Church. Louisville: Westminster John Knox Press, 1989.

Hattu, Justitia Vox Dei. "Crossing the Bridge: Christian Education for Enhancing Adult Meaning-Making Oriented for Transformation in the Contemporary Context of Indonesia." Ph.D. diss. Yonsei University, 2014.

\footnotetext{
${ }^{34}$ Seymour, Mapping Christian Education, 20.
} 
- Mewarga dengan Hati: Pembelajaran Transformatif sebagai Respons Pedagogis Kristiani terbadap Tantangan Pendidikan Kewarganegaraan dalam Konteks Indonesia Masa Kini. Jakarta: BPK Gunung Mulia, 2018.

Kartajaya, Hermawan. Citizen 4.0: Menjejakkan Prinsip-Prinsip Pemasaran Humanis di Era Digital. Jakarta: Gramedia, 2019.

Lewier, F.C. "Pendidikan Agama Kristen yang Partisipatif dan Transformatif dalam Konteks Indonesia." Dalam Memperlengkapi bagi Pelayanan dan Pertumbuhan: Kumpulan Karangan Pendidikan Kristiani dalam Rangka Penghormatan kepada Pdt. Prof. Dr. Robert R. Boeblke, eds., Kadarmanto Hardjowasito, Jan S. Aritonang, dan Martin L. Sinaga, 215-224. Jakarta: BPK Gunung Mulia, 2002.

Lickona, Thomas. Mendidik untuk Membentuk Karakter: Bagaimana Sekolah dapat Mengajarkan Sikap Hormat dan Tanggung Jawab. Jakarta: Bumi Aksara, 2013.

Little, Sara. To Set One's Heart: Belief and Teaching in the Church. Atlanta: John Knox Press, 1983.

Miller, Randolph Crump. Educating for Christian Living. New Jersey: Prentice Hall, 1959.

Pohl-Patalong, Uta. "Learning in School and in the Congregation: A Comparison with regard to Conformation Work." In Basics of Religious Education. Eds., Martin Rothgangel, et.al., 113-130. Gottingen: V \& R Unipress, 2014.

Posumah-Santosa, Jedida T. "Pendidikan Agama Kristen di Sekolah: Suatu Bidang Studi atau Asuhan Iman Kristen?” Dalam Ajarlah Mereka Melakukan: Kumpulan Karangan seputar Pendidikan Agama Kristen. Ed., Andar Ismail, 152-166. Jakarta: BPK Gunung Mulia, 1998.

Seymour, Jack L. \& Donald E. Miller, eds. Contemporary Approaches to Christian Education. Nashville: Abingdon Press, 19820.

Seymour, Jack L., ed. Mapping Christian Education. Nashville: Abingdon Press, 1997.

Schweitzeir, Friedrich. "Religious Education as a Task of the School." In Basics of Religious Education. Eds., Martin Rothgangel, et al., 81-93. Gottingen: V \& R Unipress, 2014.

Stefanus, Daniel. Pendidikan Agama Kristen Kemajemukan. Bandung: Bina Media Indonesia, 2009.

Tye, Karen B. Basics Christian Education. Danvers, MA: Chalice Press, 2000.

Wermke, Michael. "Religion in School Outside Religious Education." In Basics of Religious Education. Eds., Martin Rothgangel, et.al., 95-111. Gottingen: V \& R Unipress, 2014. 